\title{
GEOGRAPHIC VARIATION OF CHLOROPLAST DNA HAPLOTYPES IN Acacia aulacocarpa A. Cunn. ex Benth
}

\author{
Anthonius YPBC Widyatmoko ${ }^{1}$ and Susumu Shiraishi ${ }^{2}$
}

Received : 29 January 2013, Accepted : 26 June 2013

\begin{abstract}
The geographic variation of chloroplast DNA (cpDNA) haplotypes of Acacia aulacocarpa was investigated among 18 natural populations. These populations represent the geographical range of the species in New Guinea Island and Queensland. Single strand conformation polymorphism (SSCP) was used for the analysis. Two noncoding regions of $\mathrm{cpDNA}$, the intron region of the $\operatorname{trn} \mathrm{L}$ gene and the intergenic spacer region between the $\operatorname{trn} \mathrm{P}$ and $\operatorname{trn} \mathrm{W}$ genes, were analyzed, and four haplotypes $(\mathrm{A}, \mathrm{B}, \mathrm{C}$, and $\mathrm{D})$ were recognized. The haplotype distribution corresponded with the geographic distribution of the populations. Based on four cpDNA haplotypes, the eighteen populations were divided into three groups: New Guinea Island, Northern Queensland and Southern Queensland. Haplotype $C$ was observed only in the New Guinean populations, while the other three haplotypes $(\mathrm{A}, \mathrm{B}$, and $\mathrm{D})$ were found in Queensland only. All of these three haplotypes were observed in Southern Queensland, whereas haplotype B was found only in the Northern Queensland populations. The cpDNA haplotype diversity of this species seemed to be highest in southern Queensland.
\end{abstract}

Keywords: Acacia aulacocarpa, geographic variation, Chloroplast DNA, non-coding region, haplotype, PCR-SSCP

\section{INTRODUCTION}

The genus Acacia is a common forest tree species originated from Papua and Papua New Guinea (New Guinea Island), Australia and neighboring islands. Among Acacia species, $A$. mangium Willd. and $A$. auriculiformis Cunn. ex. Benth. are considered as the most important species for plantation, and some genetic improvement programs have been carried out in Southeast Asia (Thompson, 1994). In addition, $A$. aulacocarpa A. Cunn. ex Benth and $A$. crassicarpa Cunn. ex Benth are widely distributed in tropical areas. These species are utilized in forest plantation for pulp and paper. Genetic diversities in $A$. mangium, $A$. auriculiformis, and $A$. crassicarpa have been discussed by Moran et al. (1988 and 1989), Khasa et al., (1994), Wickneswari and

${ }^{1}$ Center for Forest Biotechnology and Tree Improvement, Yogyakarta

${ }^{2}$ Laboratory of Silviculture, Faculty of Agriculture, Kyushu University, Fukuoka, Japan

"Corresponding Author: aviwicaksono@yahoo.com
Norwati (1993), Butcher et al., (1998), Widyatmoko et al., (2010) and Widyatmoko and Shiraishi (2011). Several studies have been carried out in species trial, provenance trial, nursery practice and fertilization to determine superior growth performance, adaptability, pest and disease resistance of the genus (Thompson, 1994). Phylogenetic study on Acacia has been reported by Brown et al. (2008), Byrne et al. (2001 and 2002) and Clarke et al. (2000).

A. aulacocarpa belongs to the section of Juliflorae, subgenus Phyllodineae (Brain and Maslin, 1996; Pettigrew and Watson, 1975). This species is naturally distributed in diverse habitats over a wide geographic range, including four states in northern and eastern Australia (Queensland/ QLD, New South Wales/NSW, Northern Territory/NT, and Western Australia/WA), Papua New Guinea (Western Province/WP), and Indonesia (Papua/PI). Based on morphological differences, this species has been divided into 5 subspecies: $A$. aulacocarpa subsp. A (NT, WA), $A$. aulacocarpa subsp. B (WP, PI), $A$. aulacocarpa subsp. 
C (northern QLD), A. aulacocarpa subsp. D (northern QLD), and A. aulacocarpa subsp. E (southern QLD, NSW) (Thomson, 1994). McDonald and Maslin (2000) revised taxonomic of Acacia aulacocarpa Cunn. ex Benth. and its seven close relatives, mainly based on their mode of pod dehiscence. These species divided into two subgroups: $A$. aulacocarpa subgroup and $A$. crassicarpa subgroup. Acacia aulacocarpa subgroup consists of $A$. aulacocarpa, $A$. celsa and $A$. disparrima, while $A$. crassicarpa subgroup comprise of $A$. crassicarpa, $A$. lamprocarpa, $A$. midgleyi, $A$. peregrina and $A$. wetarensis.

Field trials regarding to the species have been carried out in several countries. A. aulacocarpa subspecies C (Thomson, 1994), is kown as highly productive and high survival rate at most of the trial sites. This species demonstrates high pulp productivity $\left(330 \mathrm{~kg} / \mathrm{m}^{3}\right)$ especially for $\mathrm{kraft}$ pulping. In comparison with other Acacia`s species ( $A$. auriculiformis, $A$. cincinnata, $A$. crassicarpa and $A$. mangium), $A$. aulacocarpa yields more for pulping (Balodis and Clark, 1998).

Single-strand conformation polymorphism (SSCP) is a simple, fast and very sensitive method for the identification of nucleotide-sequence polymorphisms. This technique is performed without sequencing and able to detect small changes in DNA such as single base substitutions, deletions, and insertions (Orita et al., 1989). Hayashi (1991) combined this method with PCR, and developed a simple method of analysis referred to as PCR-SSCP. This method has greatly increased the efficiency of the marker and appears to be a useful tool for studying genetic variation. It has been utilized in studies on the detection of inheritance and molecular variation (Bodenes et al., 1996), chloroplast DNA variation, typing and identification (Maeda and Shiraishi, 1997; Watano et al., 1995), and genetic mapping (Judelson et al., 1995). Hongyo et al. (1993) reported the improvement of SSCP method becomes simple method called 'Cold-SSCP'. Recently, the SSCP method has been further modified and utilized for DNA genome analysis (Grace et al., 1995).

The chloroplast genome is conservative in its evolution. Chloroplast DNA (cpDNA) possesses many peculiar characteristics, such as uniparental inheritance, the lack of recombination and repeated sequences, and low variability compared with nuclear DNA (Birky, 1988; Wolfe et al., 1987). These characteristics lead to the expectation that diversity within a population is very low and differentiation between populations might be easily detected. This would be especially observable in species with geographically isolated populations and/or small populations.

Studies of the genetic diversity of the Acacia aulacocarpa have been reported by Widyatmoko and Shiraishi (2010). In this study, however, only six samples have been used and compared to the others three Acacia species of which $A$. aulacocrapa had the highest genetic diversity. Information of genetic diversity for all natural distribution of $A$. aulacocarpa is needed. Therefore, reserach was carried out with main objective to elucidate genetic diversity and genetic distribution of the species.

\section{MATERIAL AND METHOD}

\section{A. Plant Materials}

A total of 87 individuals (seeds) originating from 18 populations were used in this study (Figure 1 and Table 1). The seed samples were obtained on 1994 from the Australian Tree Seed Centre of the CSIRO (Commonwealth Scientific and Industrial Research Organization), Australia and from the Forest Tree Improvement Research and Development Institute, Indonesia. The populations were distributed in Indonesia, Papua New Guinea, and QLD (corresponding populations: 1,8 and 9, respectively). Population latitudes ranged from $7.45^{\circ} \mathrm{S}$ (Papua, Indonesia) to $27.17^{\circ} \mathrm{S}$ (Samford, QLD); altitudes ranged from $6 \mathrm{~m}$ a.s.l (N. Yeppoon, QLD) up to $720 \mathrm{~m}$ a.s.l (Buckley, QLD). For each population, 2-6 trees are represented; only one seed from each individual tree $(\mathrm{n}=87)$ was used. Similar number of samples per population for analysing chloroplast DNA variation also reported by Zulfahmi et al. (2010) and Bordacs et al. (2002). 


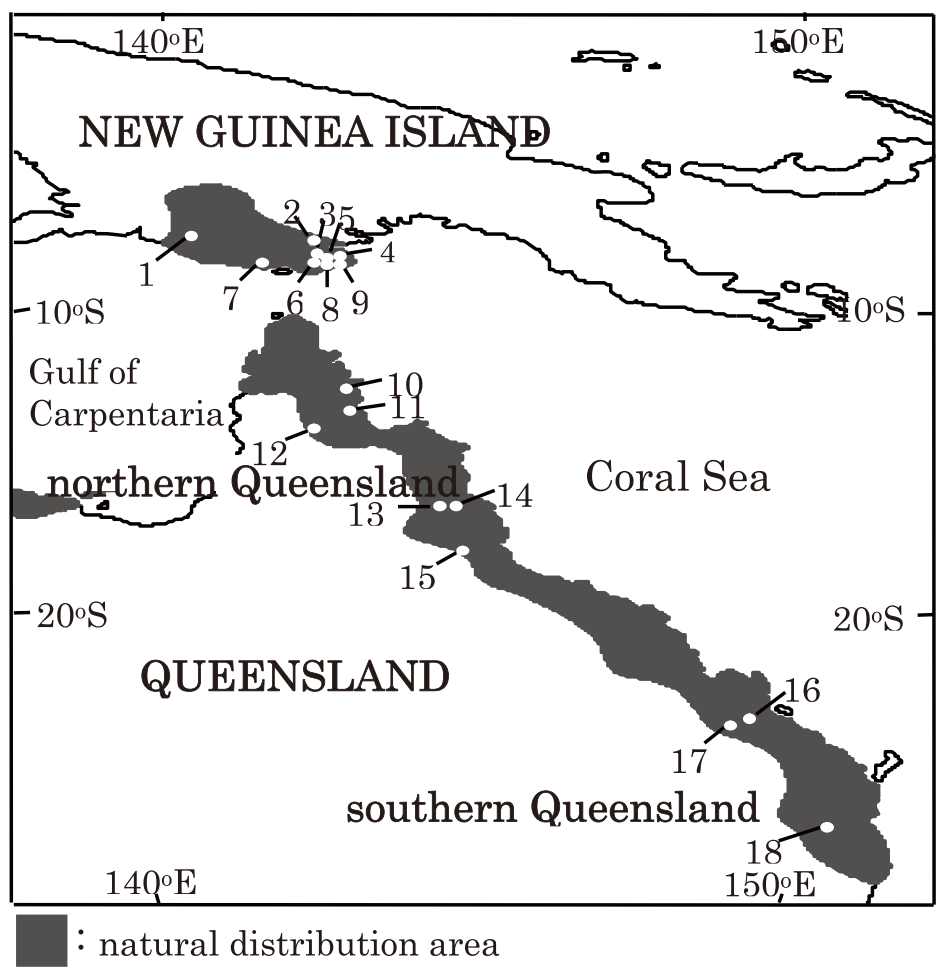

Figure 1. Natural Distribution of $A$. aulacocarpa and location of population invested Remarks: Population number refers to Table 1.

\section{B. DNA Extraction}

Total genomic DNA was extracted using a modified SDS method (Guan et al., 2011). Each seed was grounded using $400 \mu \mathrm{l}$ SDS extraction buffer, which contained of $50 \mathrm{mM}$ Tris- $\mathrm{HCl}(\mathrm{pH}$ 9.0), $1 \%(\mathrm{w} / \mathrm{v})$ SDS, $10 \mathrm{mM}$ EDTA, and $0.5 \%$ $(\mathrm{v} / \mathrm{v})$ 2-Mercaptoethanol. After incubation at $65^{\circ} \mathrm{C}$ for $60 \mathrm{~min}, 200 \mu \mathrm{l}$ of $7.5 \mathrm{M}$ ammonium acetate was added. The solution was kept on ice for $30 \mathrm{~min}$, and was then centrifuged at $0^{\circ} \mathrm{C}$ at $15,000 \mathrm{rpm}$ for $40 \mathrm{~min}$. The sample in aqueous phase $(400 \mu \mathrm{l})$, was transferred to a new tube, and the DNA was precipitated by the addition of 400 $\mu \mathrm{l}$ isopropanol. After circa $10 \mathrm{~min}$, the precipitate was collected by centrifugation at $15,000 \mathrm{rpm}$ for 10 min. The supernatant was completely removed, and the pellet was washed twice with 1.0 $\mathrm{ml}$ of $70 \%$ Ethanol. After washing, the pellet was then vacuumed in an evaporator for $2 \mathrm{~min}$, then it was resuspended in $100 \mu \mathrm{l}$ purified $\mathrm{H}_{2} \mathrm{O}$. Finally, the crude solution was purified using a GeneClean III Kit (BIO 101).

\section{PCR Amplification}

The $10 \mu \mathrm{l}$ PCR reaction mixture contained $2 \mathrm{ng}$ genomic DNA, $0.25 \mu \mathrm{M}$ of each primer, $10 \mathrm{mM}$ Tris- $\mathrm{HCl}$ ( $\mathrm{pH}$ 8.3), $10 \mathrm{mM} \mathrm{KCl,} 3.0 \mathrm{mM} \mathrm{MgCl}_{2}, 0.2$ $\mathrm{mM}$ each of dNTPs, and 0.5 unit of AmpliTaq DNA polymerase, Stoffel Fragment (PerkinElmer). PCR was performed using a GeneAmp PCR System, Model 9600 (Perkin-Elmer). The conditions of amplification were as follows: $95^{\circ} \mathrm{C}$ for $60 \mathrm{~s}$, and 30 cycles of $30 \mathrm{~s}$ at $94^{\circ} \mathrm{C}, 30 \mathrm{~s}$ at $55^{\circ} \mathrm{C}$, and $90 \mathrm{~s}$ at $72^{\circ} \mathrm{C}$, followed by $60 \mathrm{~s}$ at $72^{\circ} \mathrm{C}$.

In this study, six pairs of primers (Table 2) were used to amplify six cpDNA regions. The four regions were as follows: one intron region of the trnL gene (CS2; B49317/A49855) and three intergenic spacer regions, namely, those between the $\operatorname{trn} \mathrm{L}$ and $\operatorname{trn} \mathrm{F}$ genes (CS3; B49873/A50272), between the $\operatorname{trn} \mathrm{D}$ and $\operatorname{trn} \mathrm{Y}$ genes (CS4; $\mathrm{S} 4 \mathrm{U} / \mathrm{CS} 4 \mathrm{~L})$, and between the $\operatorname{trn} \mathrm{P}$ and $\operatorname{trn} \mathrm{W}$ genes (CS5; CS5U/CS5L). Two regions (CS5a and CS5b) originated from the CS5 region were also amplified with two primer pairs (CS5aCS5aU/ CS5aL and CS5bU/CS5bL), respectively. 
Table 1. Details of seedlot number and location of sample populations of Acacia aulacocarpa

\begin{tabular}{lccccc}
\hline No. Population & $\begin{array}{c}\text { No. of } \\
\text { seeds }\end{array}$ & Seedlot No. & $\begin{array}{c}\text { Latitude } \\
\left.{ }^{\circ} \mathrm{S}\right)\end{array}$ & $\begin{array}{c}\text { Longitude } \\
\left({ }^{\circ} \mathrm{E}\right)\end{array}$ & $\begin{array}{c}\text { Altitude } \\
(\mathrm{m} \text { a.s.l. })\end{array}$ \\
\hline
\end{tabular}

\section{New Guinea}

1. Kuel, Iria Jaya

2. Makapa WP

3. Isago Arimia River WP

4. Duaba WP

5. Wasua Pedeya WP

6. Kapal NW of Wipim WP

7. Derideri E Morehead WP

8. Wipim WP

9. Balimo

District

\section{Northern Queensland}

Old Rock

11. Mcil Wraith Range

12. Piccaninny Creek

13. $10 \mathrm{~K} \mathrm{NW} \mathrm{Mt}$. Molloy

14. Garioch

15. Buckley Logging Area

\section{Southern Queensland}

$\begin{array}{ll}6 & 1001,1002,1003,1004, \\ & 1005,1006 \\ 5 & 16974-\mathrm{M}(3,7,12,16,19) \\ 5 & 16948-\mathrm{AI}(3,4,5,6,7)\end{array}$

5 16949-AD $(2,4,6,8,10)$

5 16950-AW $(1,11,21,31,37)$

5 16981-BVG (1651, 1653, $1654,1655,1659)$

5 16989-MM (969, 970, 971, 974, 975)

5 16976-KER $(2,6,10,13,16)$

5 16946-AKO $(1,12,22,32$, 42)

\begin{tabular}{|c|c|}
\hline 5 & $\begin{array}{l}\text { 18358-GJM }(1377,1383, \\
1384,1385,1386)\end{array}$ \\
\hline 4 & $\begin{array}{l}18001-\mathrm{T}(1142,1143,1145, \\
1146)\end{array}$ \\
\hline 2 & 16136-JMO $(1459,1463)$ \\
\hline 5 & 17905-TREE $(1,2,3,4,5)$ \\
\hline 5 & $\begin{array}{l}\text { 13866-BVG }(2939,3940, \\
2941,2942,2943)\end{array}$ \\
\hline 5 & $\begin{array}{l}\text { 13865-BVG }(2921,2935, \\
2936,2937,2938)\end{array}$ \\
\hline
\end{tabular}

$\begin{array}{lll}7.45 & 140.45 & 45 \\ 7.56 & 142.35 & 35 \\ 8.10 & 142.41 & 10 \\ & & \\ 8.13 & 142.58 & 25 \\ 8.17 & 142.52 & 52 \\ 8.37 & 142.47 & 40 \\ 8.40 & 141.50 & 30 \\ & & \\ 8.47 & 142.52 & 45 \\ 8.50 & 142.58 & 12\end{array}$

12.50

143.18

15

13.44

143.20

500

13.90

142.48

40

16.40

142.15

420

16.40

145.18

400

17.90

145.37

720

2936, 2937, 2938)

$\begin{array}{rlrrr}5 & 17739-G B(22,25,27,28, & 23.50 & 151.00 & 70 \\ & 73) \\ 5 & \begin{array}{l}14591-P W O(174,175,178, \\ 184,185)\end{array} & 23.60 & 150.45 & 6 \\ 5 & \begin{array}{l}17891-G B(96,97,98,99, \\ 100)\end{array}\end{array}$


Table 2. Primer sequences of cpDNA non coding regions used in this study

\begin{tabular}{|c|c|c|c|c|}
\hline Region & Code & & Primer sequence $\left(5^{\prime}-3^{\prime}\right)$ & Reference \\
\hline $\operatorname{trn} \mathrm{L}$ intron & $\mathrm{CS} 2$ & $\begin{array}{l}\text { B } 49317 \\
\text { A } 49855 \\
\text { sCS2U } \\
\text { sCS2L }\end{array}$ & $\begin{array}{l}\text { CGAAATCGGTAGACGCTACG } \\
\text { GGGGATAGAGGGACTTGAAC } \\
\text { tgtaaaacgacggccagtCGAAATCGGTAGACGCTACG } \\
\text { caggaaacagctatgaccGGGGATAGAGGGACTTGAAC }\end{array}$ & $\begin{array}{l}\text { Taberlet et al. } \\
\text { (1991) }\end{array}$ \\
\hline $\operatorname{trn} \mathrm{L}-\operatorname{trn} \mathrm{F}$ & CS3 & $\begin{array}{l}\text { B49873 } \\
\text { A50272 }\end{array}$ & $\begin{array}{l}\text { GGTTCAAGTCCCTCTATCCC } \\
\text { ATTTGAACTGGTGACACGAG }\end{array}$ & $\begin{array}{l}\text { Taberlet et al. } \\
\text { (1991) }\end{array}$ \\
\hline $\operatorname{trn} \mathrm{D}-\operatorname{trn} \mathrm{Y}$ & CS4 & $\begin{array}{l}\text { CS4U } \\
\text { CS4L }\end{array}$ & $\begin{array}{l}\text { TGACAGGGCGGTACTCTAAC } \\
\text { CGATGCCCGAGTGGTTAATG }\end{array}$ & $\begin{array}{l}\text { Shiraishi et al. } \\
\text { (unpublished) }\end{array}$ \\
\hline $\operatorname{trn} \mathrm{P}-\operatorname{trn} \mathrm{W}$ & $\begin{array}{l}\text { CS5 } \\
\text { CS5a } \\
\text { CS5b }\end{array}$ & $\begin{array}{l}\text { CS5U } \\
\text { CS5L } \\
\text { CS5aU } \\
\text { CS5aL } \\
\text { CS5bU } \\
\text { CS5bL }\end{array}$ & $\begin{array}{l}\text { TTGGTAGCGTGTTTGTTTTGGG } \\
\text { TACGGCATCAGGTTTTGGAGAC } \\
\text { GTGACCCCAATTCATCTTGC } \\
\text { TTCCCTAGTTAACTCTGGCT } \\
\text { TAAATCATTTTATGTGACCC } \\
\text { CGTCATTGTTCCCTATGGCT }\end{array}$ & $\begin{array}{l}\text { Isoda and Shiraishi } \\
\text { (1999) } \\
\text { Newly-designed } \\
\text { In this study } \\
\text { Newly-designed } \\
\text { In this study }\end{array}$ \\
\hline
\end{tabular}

Lower case indicates -21M13 primer or M13 Rev primer (Perkin-Elmer)

\section{SSCP Analysis}

PCR products $(2.5 \mu \mathrm{l})$ were mixed with $12 \mu \mathrm{l}$ of loading buffer containing $77 \%$ formamide, $0.25 \%$ $\mathrm{BPB}$, and $1 \mathrm{x}$ TBE. The solution was concentrated for 15 minutes using a vacuum evaporator, denatured for $5 \mathrm{~min}$ at $94^{\circ} \mathrm{C}$, then immediately cooled on ice, and loaded onto $7 \%$ polyacrylamide (39:1 acrylamide to bis acrylamide) TBE gel. Depending on the length of PCR product, the electrophoresis was run for 2 or 4 hours at 1.5 $\mathrm{V} / \mathrm{cm}$ and at a constant temperature of $10^{\circ} \mathrm{C}$ in $1 \mathrm{x}$ TBE running buffer. The gel was stained with a $0.5 \mu \mathrm{g} / \mathrm{ml}$ solution of ethidium bromide in $1 \mathrm{x}$ TBE buffer for $15 \mathrm{~min}$. The SSCP bands were visualized using a $302 \mathrm{~nm}$ UV transilluminator.

\section{E. Cloning of DNA Fragments}

The PCR and SSCP assays revealed two duplicated DNA fragments in the CS5 region (Fig. 3). To determine the sequence of each fragment, a cloning technique was adopted. Each fragment was cut from the gel and used as a template for the next PCR. PCR amplification was performed again for each fragment using the same primers as those used for CS5 (CS5U and CS5L). The two PCR products were ligated with pGEM vector (Primega), and were transformed into E. coli (JM109 High Efficiency Competent Cell) according to the method recommended by the suppliers. The inserted DNA regions were directly amplified from colonies using colony PCR with the following primers: 5' TCCGGCTCGTATGT-TGTGTGGA-3' and 5'GTGCTGC-AAGGCGATTAAGTTGG-3' (Hattori, 1997). DNA amplification was carried out using the above-mentioned PCR composition, except with an extremely small E. coli colony as a template DNA. PCR was performed using a GeneAmp PCR System, Model 9600 (Perkin-Elmer) with the thermal profile of $95^{\circ} \mathrm{C}$ for $60 \mathrm{~s} ; 29$ cycles of $15 \mathrm{~s}$ at $96^{\circ} \mathrm{C}$, and $120 \mathrm{~s}$ at $70^{\circ} \mathrm{C}$; followed by one cycle of $15 \mathrm{~s}$ at $96^{\circ} \mathrm{C}$ and 10 min at $70^{\circ} \mathrm{C}$. The PCR products were purified with a GeneClean III Kit (BIO 101) and used as templates for sequencing.

\section{G. Sequencing}

In addition to the colony-PCR products mentioned above, the CS2 region was amplified as templates for sequencing using a primer pair $(\mathrm{sCS} 2 \mathrm{U} / \mathrm{sCS} 2 \mathrm{~L})$ shown in Table 1. A $20 \mu \mathrm{l}$ reaction mixture contained $4 \mathrm{ng}$ of genomic DNA, $0.25 \mu \mathrm{M}$ of each primers, $20 \mathrm{mM}$ Tris- $\mathrm{HCl}$ (pH 8.0), $100 \mathrm{mM} \mathrm{KCl}, 2.0 \mathrm{mM} \mathrm{MgCl}, 1 \mathrm{mM}$ DTT, $0.25 \mathrm{mM}$ of each dNTP, and 1.0 unit of TaKaRa ExTaqTM (TAKARA). PCR was performed with a Gene Amp PCR System, Model 9600 (Perkin-Elmer). The conditions of amplification were $95^{\circ} \mathrm{C}$ for $60 \mathrm{~s}$, and 30 cycles of 
$30 \mathrm{~s}$ at $94^{\circ} \mathrm{C}, 30 \mathrm{~s}$ at $45^{\circ} \mathrm{C}$, and $90 \mathrm{~s}$ at $72^{\circ} \mathrm{C}$, followed by $60 \mathrm{~s}$ at $72^{\circ} \mathrm{C}$. In order to separate the amplified DNA from residual primers, all reactions were pooled and subjected to electrophoresis in a $1.5 \%(\mathrm{w} / \mathrm{v})$ low-meltingpoint agarose gel using TBE buffer. The desired DNA fragment was cut out of the gel and recovery was obtained using QIAEX II (QIAGEN). Sequencing was performed with a Thermo Sequanase pre-mixed cycle sequence kit (Amersham) and two sequence primers (PerkinElmer-21M13: 5'-TGTAAAACGACGGCCAGT-3' and M13 Rev: 5' CAGGAAACAGCTATGACC-3') using HITACHI SQ5500 Sequencer.

\section{RESULT}

\section{A. PCR-SSCP Profile}

Of the four DNA regions where the cpDNA variation was surveyed in $A$. aulacocarpa, two regions (CS2 and CS5) showed polymorphisms, and the other two regions (CS3 and CS4) were monomorphic. In the SSCP profile of the CS2 region, two bands appeared that corresponded to the two single-strand DNAs (ssDNA) of the PCR product. Figure 2 depicts three SSCP types showing different migration patterns. These three types were referred to as $c s 2^{1}, c s 2^{2}$ and $c s 2^{3}$. In the NGI populations, all of the samples were of the $c s 2^{2}$ type (lanes b, d, f, h, i, and $\mathrm{k}$ in Figure 2). In contrast, 3 different types were observed in the QLD populations. The cs $2^{1}$ type was recognized in the populations of $\mathrm{N}$. Yeppoon and $3 \mathrm{~K} \mathrm{~S} \mathrm{Mt}$. Larcom (lanes e and g), while $c s 2^{3}$ was found only in the one sample from Samford (lane j). The remaining samples from QLD (lanes a and c) were of the same type $\left(c s 2^{2}\right)$ as those from NGI. Within-population polymorphism was detected in only two populations, namely, those from Samford and N. Yeppoon.

In the CS5 regions, three SSCP types were observed and all samples possessed four fragments (Fig. 3B). As each fragment and a single-strand DNA were in a one-to-one correspondence, the discovery of these four fragments indicates that two DNA regions were amplified by the PCR with primers CS5U and CS5L.

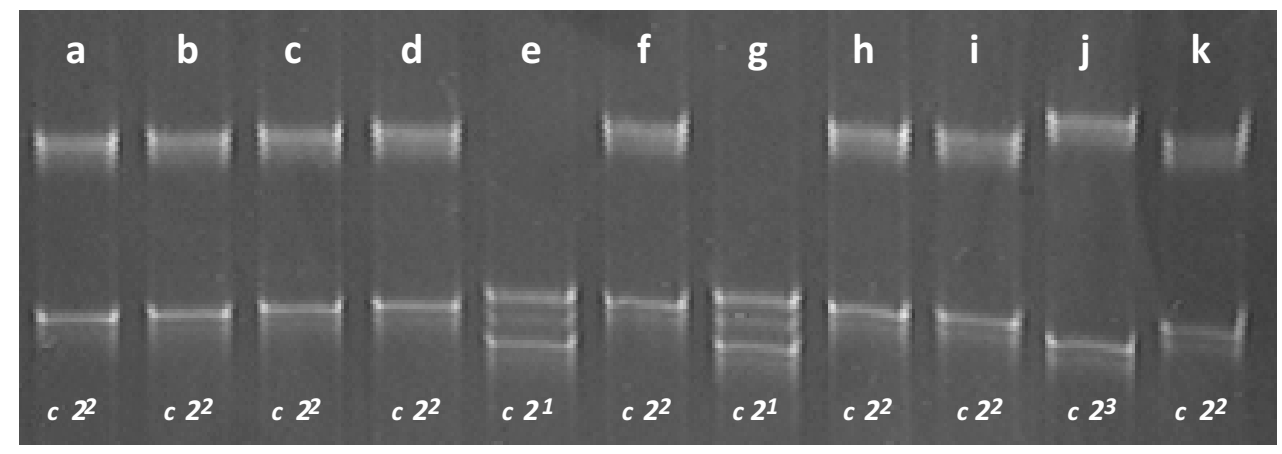

Figure 2. Cold SSCP profiles of chloroplast trnL intron (CS2) in Acacia aulacocarpa

Remarks: Fragment length of CS2 is 578 bp (same as in Fig. 6)

a-k, individual tree number: a, 13965-BVG 02921; b, 16946-AKO 00001; c, 13966-BH 02939; d, 16947-M 0000003; e, 14591-PWO 00174; f, 16948-AI 000003; g, 17739-GB 000022; h, 16949-AD 000002; i, 1001; j, 17891GB 000096; k, 16950-AW 000001. $c s 2^{\prime}$,"fast" allele; $c s 2^{2}$, "medium" allele; $c s 2^{3}$, "slow" allele

\section{B. Polymorphism in CS5 Region}

In the SSCP profile of the Cs5 regions (Fig. $3 \mathrm{~B})$, all of the samples possessed four bands. These findings clearly suggest a duplication of the region between the $\operatorname{trn} \mathrm{P}$ and $\operatorname{trn} \mathrm{W}$ genes. Three types of band patterns were observed in this region. The lanes a, b, and c, which showed slower migration patterns, belonged to the NGI populations. On the other hand, lanes e and $f$, which showed faster migration, were from the QLD populations. Furthermore, intermediate migration was recognized in a sample (lane d) from the Samford population (QLD). 


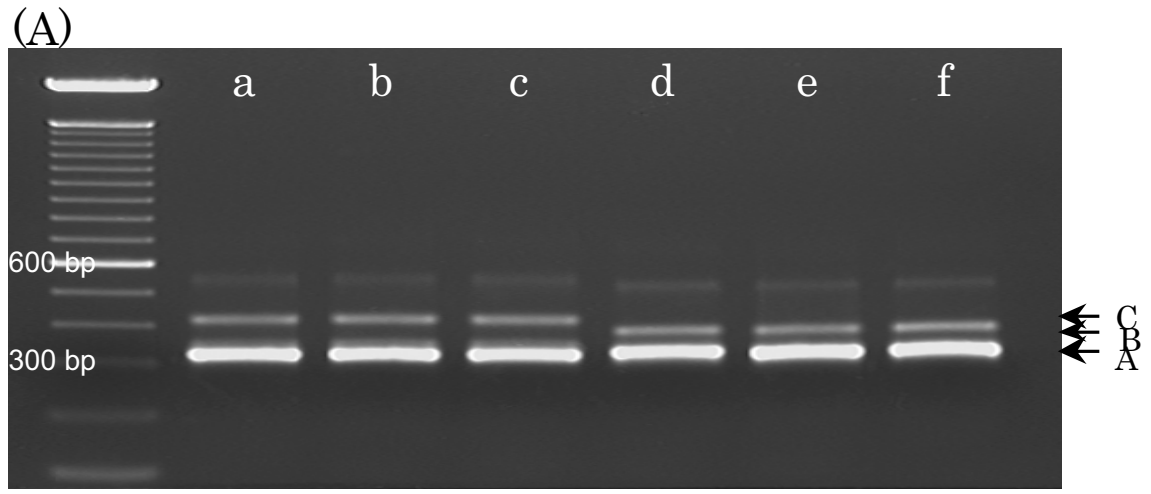

(B)

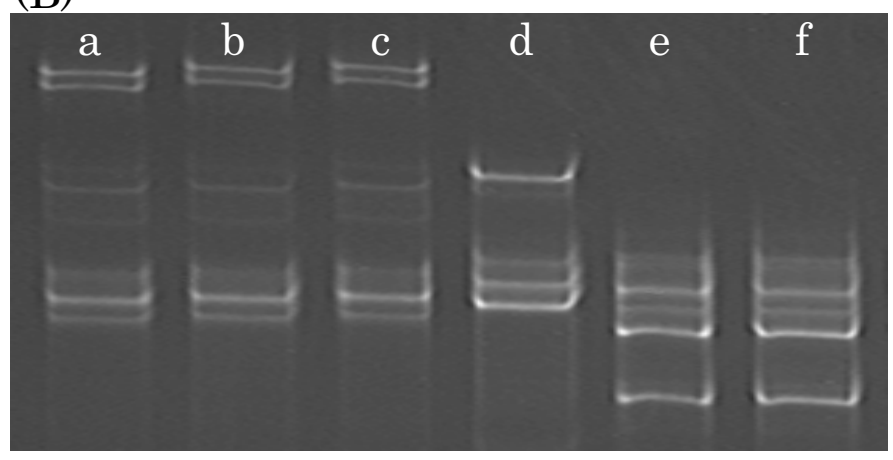

Figure 3 PCR product (A) and Cold SSCP (B) profiles of chloroplast $\operatorname{trn} \mathrm{P}-\operatorname{trn} \mathrm{W}$ spacer (CS5) in $A$. aulacocarpa

Remarks: $\mathrm{A}, \mathrm{B}$, and $\mathrm{C}$, three different PCR products.

a-f, individual tree number: a, 1001; b, 16946-AKO 00001; c, 16947-M 0000003; d, 17891-GB 000096; e, 17905TREE 1;f, 18358-GJM 1377; M, 100 bps ladder

The agarose gel electrophoretic profile of the PCR products (Figure $3 \mathrm{~A}$ ) revealed that each sample possessed 2 bands in which the fastest band (A) was thicker than the slower bands (B and C). The sequence of the duplicated regions was clarified by cloning three DNA fragments (A, B, and $C$ ). Figure 4 depicts the sequences of fragments $\mathrm{A}, \mathrm{B}$, and $\mathrm{C}$. These three sequences were highly homologous, especially fragments $\mathrm{A}$ and $\mathrm{B}$, which were completely identical except for an insertion/deletion (indel) of $40 \mathrm{bps}$. The sequence of fragment $\mathrm{C}$ was different from the former two sequences as regards five of the indels and four substitutions. From the sequence homology, these three sequences (A, B, and C) could be grouped into CS5a and CS5b. The fragments A and B reflected the CS5a region, and the fragment $\mathrm{C}$ corresponded to CS5b. Based on the sequence information, two primer pairs were newly designed to amplify the two regions (CS5a and CS5b) specifically, and SSCP variation was investigated in each region (Figure 5A and 5B).

In the CS5a region, two SSCP types with different migrations were detected (Figure 5A). The two types were referred to as $\operatorname{cs} 5 \mathrm{a}^{1}$ and $\operatorname{cs} 5 \mathrm{a}^{2}$, respectively. The cs $5 \mathrm{a}^{2}$ was found in only one sample from the Samford population (lane a). On the other hand, in the CS5b region, two SSCP types with different migrations were observed (Figure 5b). The two types were referred to as cs $5 b^{1}$ and cs $5 b^{2}$. The odd lanes in Figure $5 B$ were the samples from Queensland populations, whereas the even lanes were from NGI. This revealed that these two groups, NGI and Queensland, possessed quite different SSCP types of CS5b region. 

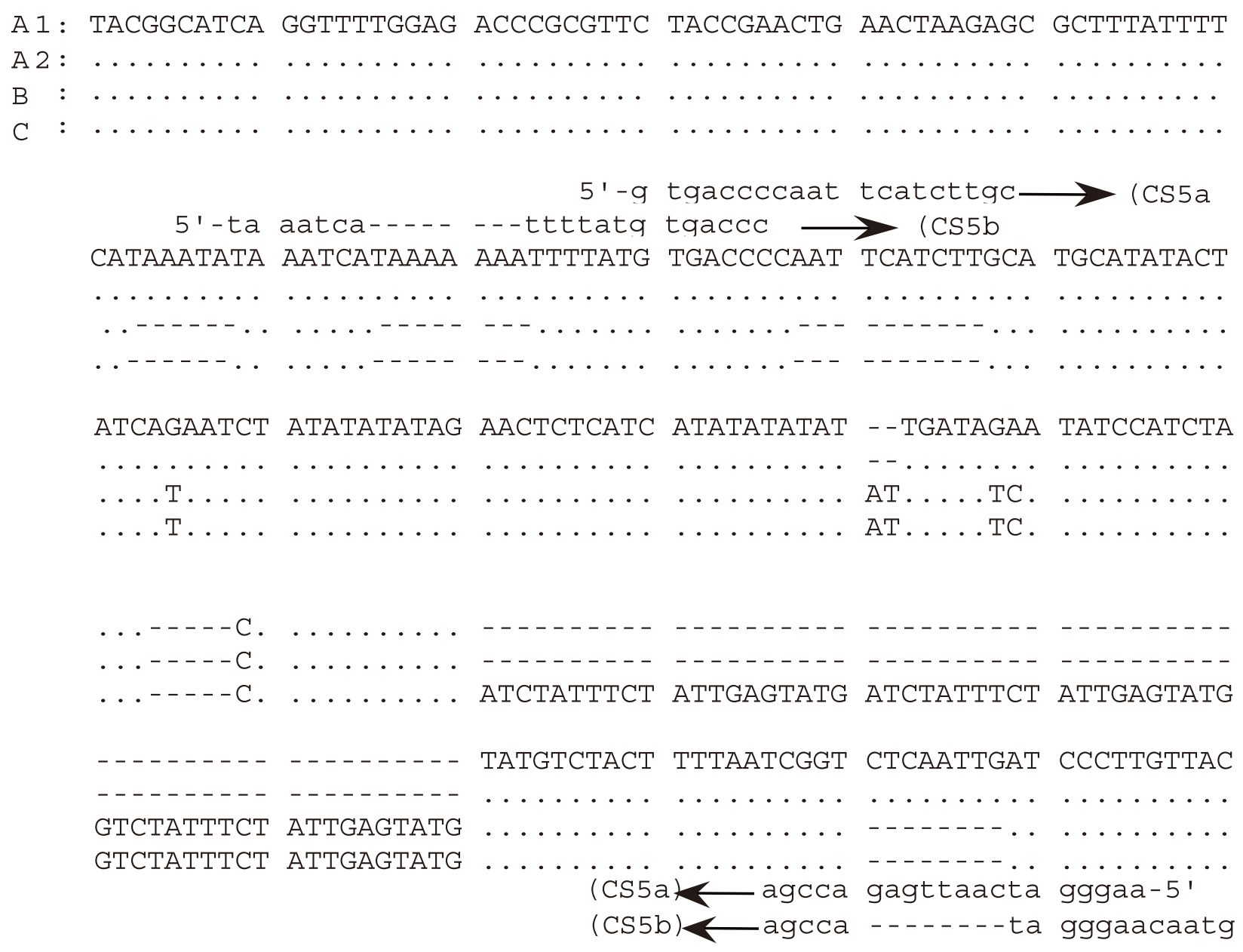

TCATCATAAg ATAGGTAATA GTTAGGGATA GGgATGACAg GATTTGAACC CGTGACATTT

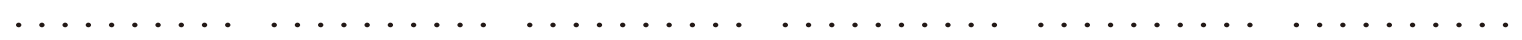

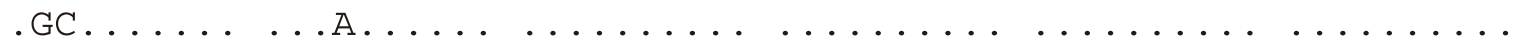

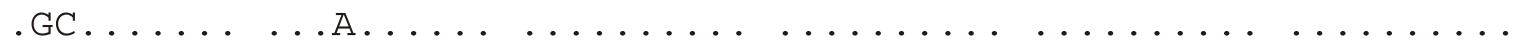
agt -5 '

TGTACCCAAA ACAAACACGC TACC

$\ldots \ldots \ldots \ldots \ldots \ldots \ldots$

$\ldots \ldots \ldots \ldots \ldots \ldots \ldots$

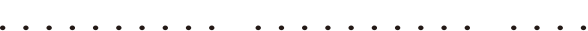

Figure 4. A partial Sequences of chloroplast $\operatorname{trn} \mathrm{P}-\operatorname{trn} \mathrm{W}$ (Cs5) spacer of the three different PCR products (A, B, and C) as shown in Figure 3

Remarks: Two primer pairs (CS5a and CS5b) were designed to amplify the two duplicated regions. A dash (-) denotes a deletion 
(A)

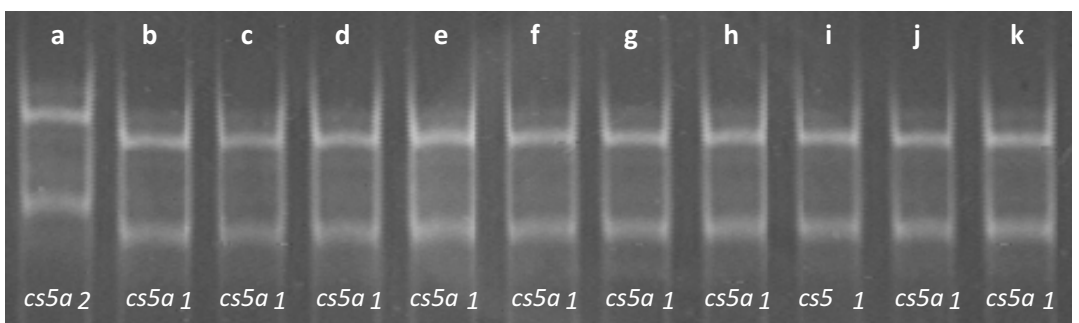

(B)

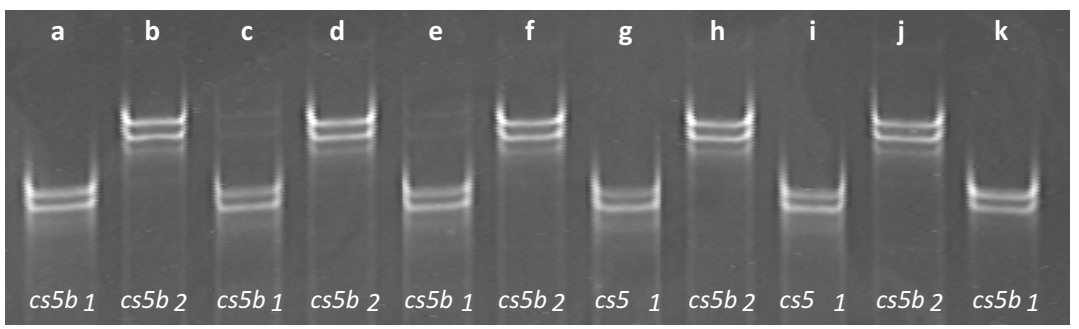

Figure 5 (A). Cold SSCP profiles of CS5a regions in Acacia aulacocarpa

a-k, individual tree number : a, 17891-GB 000096; b, 17739-GB 000073; c, 1006, d, 16950AW 000037; e, 17891-GB 000100; f, 16971-KER 00016; g, 17905-TREE 5; h, 16981-BVG 01659; i, 18358-GJM 1386; j, 16989-MM 000975; k, 16136-JMO 01463. cs5a $a^{\prime}$, "fast" allele; cs $5 a^{2}$,"slow" allele

(B). Cold SSCP profiles of Cs5b regions in Acacia aulacocarpa

a-k, individual tree number : a, 17905-TREE 1; b, 16976-KER 00002; c, 18358-GJM 1377; d, 16981-BVG 01651; e, 1800-T 1142; f, 16989-MM 000969; g, 16136-JMO 01459; h, 16946-AKO 00012; i, 13865-BVG 02935; j, 16947-M 0000007; k, 13866-BVG 02940. $c s 5 b^{1}$, "fast" allele; $c 55 b^{2}$, "slow" allele

\section{Sequences of Polymorphic Regions}

The sequences of SSCP types in each polymorphic region are shown in Figure 6. It was confirmed that all of the SSCP polymorphisms in the three regions reflected differences in sequence. In the cpDNA trnL intron region (CS2) in which three SSCP types were detected, all sequence types had the same length (578 bps); furthermore, no indel was detected. Single-base substitution, however, was recognized among the three types. Cs2 ${ }^{1}$, observed in $3 \mathrm{~K} \mathrm{~S} \mathrm{Mt.} \mathrm{Larcom}$ and N. Yeppoon populations reflected a singlebase transition ( $G$ to $A$ ) in the 177th base. However, the $c s 2^{3}$ detected in one sample in the Samford population reflected a single transition (C to $\mathrm{T}$ ) in the $228^{\text {th }}$ position.

According to the cpDNA intergenic spacer between $\operatorname{trn} \mathrm{P}$ and $\operatorname{trn} \mathrm{W}$ (CS5), two regions were analyzed using the different primer pairs. In CS5a, the two types were distinguished by a 5-base duplication and a single-base transversion (A to C). In CS5b, which clearly separated NGI from QLD, the sequence length differd between the two types. In this region, a tandem repeat with a 20-bp core sequence was recognized. $C s 5 b^{2}$ appeared only in the NGI populations that had a twice-repeat sequence, whereas $c s 5 b^{1}$ was detected only in QLD populations that had a four-foldrepeat. Moreover, a single-base substitution was detected between $c s 5 b^{1}$ and $c s 5 b^{2}$.

\section{Chloroplast DNA Haplotype Distribution}

Four different cpDNA haplotypes have been determined based on the combination of SSCP types in the three regions (Table 3). Haplotype A was a combination of $c s 2^{1}$ in CS2 region and $c s 5 a^{1}$ and $c s 5 b^{1}$ in CS5. Haplotype B was a combination of the $\operatorname{cs} 2^{2}, c s 5 a^{1}$, and $c s 5 b^{1}$. Haplotype $C$ consisted of $c s 2^{2}, c s 5 a^{1}$, and $c s 5 b^{2}$, and haplotype $\mathrm{D}$ was a combination of $\operatorname{cs} 2^{3}, \operatorname{cs} 5 a^{2}$, and $\operatorname{cs} 5 b^{1}$. 
GACTTAATTG GATTGAgCCT TGgtATgGAA ACCTACCAAg TGATAACTTT CAAATTCAgA

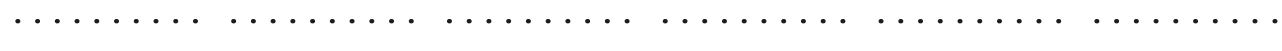

GAAACCCTGG AATTAACAAT GGGCAATCCT GAGCCAAATC CTGTTTTCCG AAAACCAAGA

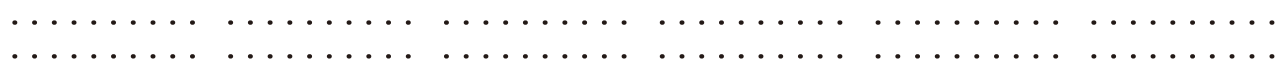

AgAgtTCAgA AAgGgagAAT AAAAtAAAAA AgGAtAgGtg CAgAgACtCA ACGgAAgCtg

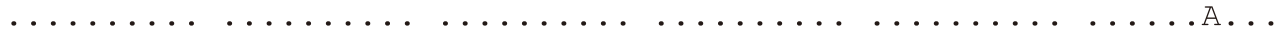

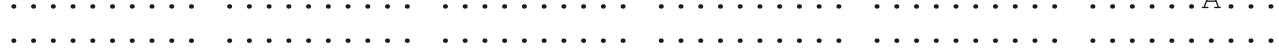

TTCTAACAAA TGgAgTTGAC GACATTTCGT TTCCTTAgTA AgGATTTCGT TTCGTTAgtA

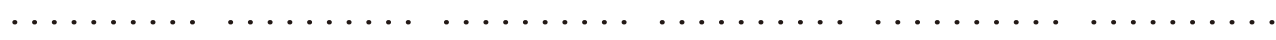

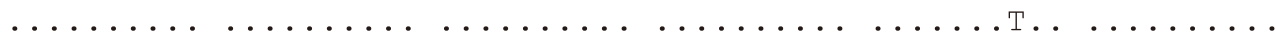

AAGAgATCCT TCCATCGAAA CTCCAGAAAA GAAAgGATCA AGgATGAGCA TACGTATACG

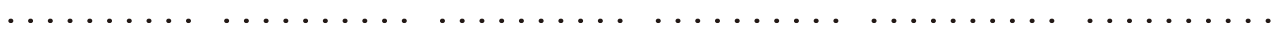

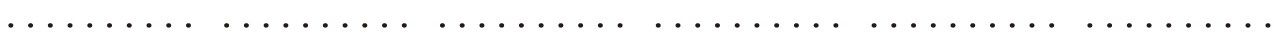

TACTGAAATA CTATTTCAAT TGATTAgACC AgACAGACCC AAAATCTCTA TTTTTTATTT

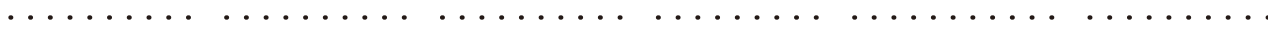

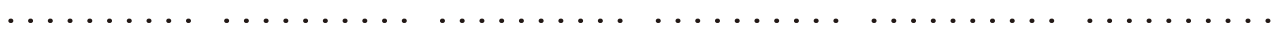

TAATATTTAT ATGACAAATA AAAgATGTGA ATCGATTCCA AgTTGAAgAA AgAATCAAAT

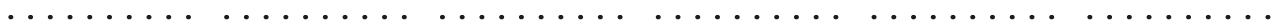

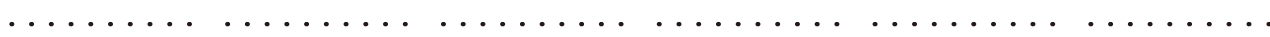

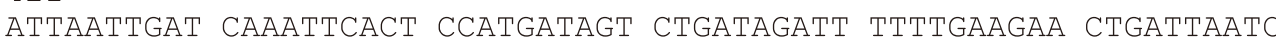

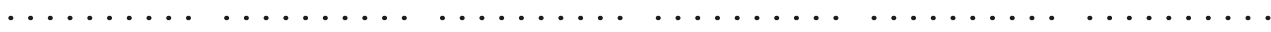

AGTAAGAGGA AAATCCGTCG ACTTTAGAAA TCGTGAGG

$\ldots \ldots \ldots \ldots \ldots \ldots \ldots \ldots \ldots \ldots \ldots \ldots \ldots \ldots$

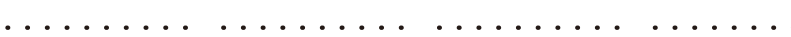

Figure 6. Sequences of chloroplast trnL intron (CS2) in A. aulacocarpa

Remarks : Only positions different from the upper sequence are shown. Each line corresponds to the different allele. The upper line, $c s 2^{2}$ allele; the middle line, $c s 2^{2}$ allele; the lower line, $c s 2^{3}$ allele

Table 3. Allele combination of each chloroplast DNA haplotype

\begin{tabular}{cccc}
\hline \multirow{2}{*}{ CpDNA haplotypes } & \multicolumn{3}{c}{ Regions } \\
\cline { 2 - 4 } & CS2* & CS5a** & CS5b F $^{* *}$ \\
\hline A & 1 & 1 & 1 \\
B & 2 & 1 & 1 \\
C & 2 & 1 & 2 \\
D & 3 & 2 & 1 \\
\hline
\end{tabular}

\footnotetext{
* Chloroplast trnL intron

** Chloroplast intergenic spacer between $\operatorname{trn} \mathrm{P}$ and $\operatorname{trn} \mathrm{W}$
} 


\section{IV.DISCUSSION}

\section{A. SSCP and Sequence Polymorphism}

Recently, PCR-SSCP analysis has proved to be a very sensitive, rapid, and easy method for detecting point mutations and other DNA polymorphisms (Rehben et al., 1997; Watano et al., 1995; Bodenes et al., 1996; Watanabe et al., 1997; Maeda and Shiraishi, 1997). So far, extensive use of this technique has been limited by disadvantages such as the need for radioactive labeling, time-consuming electrophoresis, and an accurate DNA concentration. These factors play an important role in the sensitivity and resolution of SSCP. A new method referred to as "ColdSSCP" (Hongyo et al., 1993) enabled SSCP profiles to be visualized directly with ethidium bromide staining.

The effectiveness of PCR-SSCP for detecting cpDNA haplotype polymorphism in $A$. aulacocarpa was demonstrated in this study. Orita et al. (1989) and Spinardi et al. (1991) have reported differences in SSCP band migration caused by single-base substitutions. In the present study, this method was adopted to enable single-base substitution and indel detection. In both CS5 regions (CS5a and Cs5b), sequence length variations and single-base substitutions were detected as mobility shifts in both SSCP bands. In the CS2 region, SSCP was able to distinguish three sequences that differed from each other by a single-base substitution.

\section{B. Geographical Variation in Chloroplast DNA}

In spite of the conservative evolution of the chloroplast genome, intraspecific variations of cpDNA have been widely reported (Levy et al., 1996) and cpDNA has become increasingly valuable as a genetic marker to detect intraspecific variations. CpDNA markers have been used to examine population genetics and structure, haplotype diversity, genetic diversity, and breeding systems (Hong et al., 1993; Levy et al., 1996; Watano et al., 1995). In the present study, cpDNA was adopted to estimate the geographic variation of $A$. aulacocarpa. Widyatmoko and Shiraishi (2011) reported cpNA variation of 6 samples of A. aulacocarpa using intergenic spacer between the $\operatorname{trn} \mathrm{P}$ and $\operatorname{trn} \mathrm{W}$ gene. The NGI and QLD tend to be separated based on the cpDNA haplotypes.
In this study, cpDNA haplotype variations in A. aulacocarpa in the NGI and the QLD were detected in two non-coding regions (the $\operatorname{trn} \mathrm{L}$ intron and the intergenic spacer between the $\operatorname{tr} n \mathrm{P}$ and $t r n \mathrm{~W}$ genes) by using PCR-SSCP.

Two duplicated regions were detected in the region between the trn $\mathrm{P}$ and $t r n \mathrm{~W}$ genes (CS5). By cloning and sequencing the DNA fragments, two new pairs of primers were designed, thus enabling the two regions to be specifically amplified by PCR. One of these two regions, maybe CS5b, seems to be a pseudogene. Highly homologous arrangements with cpDNA are also observed in nuclear DNA (ncDNA) (Birky, 1988). If the region was located in ncDNA, the heterozygous type with $c s 5 b^{1}$ and $c s 5 b^{2}$ should have appeared. However, no heterozygote was detected in any of the 87 samples analyzed in this study. Therefore, both regions were presumed to be located on the cpDNA. However, it cannot be ruled out that one of the two regions is located in a genome other than the cpDNA genome. A total of 7 SSCP types were detected in the three regions, and $4 \mathrm{cpDNA}$ haplotypes were identified based on a combination of the 7 SSCP types (Table 2).

Table 3 shows the relative frequencies of the four cpDNA haplotypes in 18 populations. Based on the distribution of the four identified cpDNA haplotypes, these populations could be divided into three groups. One group consisted of nine populations that were located in NGI. This group could be characterized by the appearance of haplotype $\mathrm{C}$, which this haplotype appeared only in NGI populations, and was not observed in the other populations. Another group of six populations in northern QLD was located at the latitude between 13 - $18^{\circ} \mathrm{S}$. This group was characterized by haplotype B. The haplotype B appeared also in southern QLD populations. The third group, consisting of three populations, was distributed in southern QLD (at a latitude between $\left.23-28^{\circ} \mathrm{S}\right)$. Unlike the other two groups, this group included three haplotypes, excluding haplotype B. Furthermore, variation in haplotype could be recognized between populations as well as within populations. These three populations can be divided into two more subordinate, smaller groups based on haplotype frequencies. Two populations, 3K S Mt. Larcom and $\mathrm{N}$ of Yeppoon, were distributed at an altitude of 
Table 4. Distribution of chloroplast DNA haplotypes of each Acacia aulacocarpa population in New Guinea and Queensland

\begin{tabular}{|c|c|c|c|c|c|c|}
\hline \multirow{2}{*}{ No } & \multirow{2}{*}{ Population } & \multirow{2}{*}{$\begin{array}{l}\text { No. of } \\
\text { seeds }\end{array}$} & \multicolumn{4}{|c|}{ cpDNA haplotype (\%) } \\
\hline & & & A & B & $\mathrm{C}$ & $\mathrm{D}$ \\
\hline \multicolumn{7}{|c|}{ New Guinea } \\
\hline 1. & Kuel, Irian Jaya & 6 & 0.000 & 0.000 & 1.000 & 0.000 \\
\hline 2. & Makapa WP & 5 & 0.000 & 0.000 & 1.000 & 0.000 \\
\hline 3. & Isago Arimia River WP & 5 & 0.000 & 0.000 & 1.000 & 0.000 \\
\hline 4. & Duaba WP & 5 & 0.000 & 0.000 & 1.000 & 0.000 \\
\hline 5. & Wasua Pedeya WP & 5 & 0.000 & 0.000 & 1.000 & 0.000 \\
\hline 6. & Kapal NW of Wipim WP & 5 & 0.000 & 0.000 & 1.000 & 0.000 \\
\hline 7. & Derideri E Morehead WP & 5 & 0.000 & 0.000 & 1.000 & 0.000 \\
\hline 8. & Wipim WP & 5 & 0.000 & 0.000 & 1.000 & 0.000 \\
\hline 9. & Balimo District & 5 & 0.000 & 0.000 & 1.000 & 0.000 \\
\hline \multicolumn{7}{|c|}{ Northern Queensland } \\
\hline 10. & Old Rock Hart Airstrip & 5 & 0.000 & 1.000 & 0.000 & 0.000 \\
\hline 11. & Mcil Wraith Range & 4 & 0.000 & 1.000 & 0.000 & 0.000 \\
\hline 12. & Piccaninny Creek & 2 & 0.000 & 1.000 & 0.000 & 0.000 \\
\hline 13. & 10 K NW Mt. Molloy & 5 & 0.000 & 1.000 & 0.000 & 0.000 \\
\hline 14. & Garioch & 5 & 0.000 & 1.000 & 0.000 & 0.000 \\
\hline 15. & Buckley Logging Area & 5 & 0.000 & 1.000 & 0.000 & 0.000 \\
\hline \multicolumn{7}{|c|}{ Southern Queensland } \\
\hline & 3K S Mt. Larcom & 5 & 1.000 & 0.000 & 0.000 & 0.000 \\
\hline & $\mathrm{N}$ of Yeppon & 5 & 0.800 & 0.200 & 0.000 & 0.000 \\
\hline \multirow[t]{2}{*}{18.} & Samford & 5 & 0.000 & 0.800 & 0.000 & 0.200 \\
\hline & & & 0.104 & 0.414 & 0.471 & 0.011 \\
\hline
\end{tabular}

Frequencies of cpDNA haplotypes are shown in parentheses

around $23^{\circ} \mathrm{S}$; these two populations had common haplotypes. The other population, namely, the Samford population, shared a common haplotype with the northern QLD group.

In $A$. mangium, a correlation between the cluster analysis and geographical distribution has been reported (Butcher, 1998). A. mangium has been grouped into four distinct regions, the Sidei and Ceram Islands, NGI, the northern part of northern QLD, and the southern part of northern QLD. The group in the northern part of northern QLD was more closely related to the NGI group than to that of the southern part of northern QLD. Similar results have been reported in $A$. auriculiformis (Wickneswari and Norwati, 1993). This species was divided into three distinct groups, the Northern Territory (NT), QLD, and NGI; the populations of QLD were closely related to those of NGI. In the present study, however, a strong separation was observed between the NGI and QLD populations as regards the cpDNA variation. Since Australia and NGI were separated by the rising sea level during the postglacial period ca. 10,000 years ago, it might be easily predicted that the species adapted to different environments and that the gene flow between Australia and NGI was obstructed.

A rare haplotype was detected in a restricted population. Such a phenomenon has also been recognized in the isozymes of $A$. mangium, $A$. auriculiformis, and $A$. crassicarpa (Moran et al., 1989; Wickneswari and Norwati, 1993; Khasa et al., 1994). Rare allelic variants at a particular locus were detected in only one or two populations; this could be due to mutations that arose during the postglacial period. Compared with $A$. mangium, $A$. 
auriculiformis, and $A$. crassicarpa, $A$. aulacocarpa is more widely distributed and formed larger forests in QLD. Hence, a relatively high level of genetic diversity was expected in this territory; evidence for this hypothesis was given by the polymorphic cpDNA haplotype.

The clustering of the $A$. aulacocarpa population in NGI and QLD based on cpDNA haplotypes was in agreement with that based on the morphological characteristics. No population of NT was investigated in this study. The NGI group appears to belong to $A$. aulacocarpa subsp. $\mathrm{B}$. The northern QLD group is presumed to correspond to subsps. C and D, whereas the southern QLD group corresponds to subsp. E. If these correspondences are accurate, the differentiation of cpDNA haplotypes in this study supports the subspecies classified by Thompson (1994). Distribution of eight species those clustered into 2 groups (McDonald and Maslin, 2000) also related with cpDNA haplotypes. A. aulacocarpa group ( $A$. aulacocarpa, $A$. celsa and $A$. disparrima) distributed in northern and southern QLD. However, $A$. crassicarpa group (A. crassicarpa, $A$. midgleyi, $A$. peregrina), distributed in NGI and northern QLD. Thus, both groups can be separated with cpDNA haplotypes, except some population of $A$. crassicarpa and $A$. midgleyi those distribute in southern QLD. No samples of A. lampcocarpa and $A$. wetarensis were collected in this study because both species were distributed in NT and Wetar.

The geographic distribution of cpDNA haplotypes indicated that the NGI and QLD populations could be grouped into three regions, namely NGI, northern QLD, and southern QLD. There was a large difference in the cpDNA haplotypes among groups from different geographical areas; this was especially the case in the NGI and the QLD groups. This can be utilized to an improvement program as basic information for seed orchard establishment and provenance trial and so on. In general, the necessity of intensive seed collection from many populations should be emphasized; such collection should take place especially in southern QLD, where the highest genetic diversity is maintained.

\section{CONCLUSION}

Using Cold SSCP marker of 4 chloroplast DNA regions four cpDNA haplotypes were identified (A, B, C, and D). The haplotype distribution corresponded with the geographic distribution of the populations. Based on four cpDNA haplotypes, the eighteen populations were divided into three groups, namely, New Guinea Island, Northern Queensland and Southern Queensland.

\section{ACKNOWLEDGEMENTS}

The authors would like to thank JICA (Japan International Cooperation Agency) project for genetic materials (seeds) supporting. We would also like to thank Dr. Keiya Isoda for his technical assistance.

\section{REFERENCES}

Balodis, V., \& Clarkd, N. B. (1998). Tropical acaciasthe new pulpwood. Appita J., 51,179-181.

Birky, C. W. (1988). Evolution and variation in plant choroplast and miticondrial genomes. In L. D. Gottlieb, \& S. K. Jain (Eds.), Plant Evolutionary Biology (pp. 23-54). London: Chapman and Hall Ltd.

Bodenes, C., Laigret, F., \& Kremer, A. (1996). Inheritance and molecular variations of PCRSSCP fragments in pedunculate oak (Quercus robur L.). Theor. Appl. Genet., 93, 348-354.

Bordáct, S., Popescu, F., Slade, D., Csaikl, U. M., Lesur, I., Borovics, A., et al. (2002). Chloroplast DNA variation of white oaks in northern Balkans and in the Carpathian Basin. Forest Ecology and Management, 156, 197-209.

Brain, P., \& Maslin, B. R. (1996). A serological investigation of the classification of Acacia subgenus Phyllodineae (Leguminosae: Mimosoideae). Biochem. Sys. Eco., 24, 379-392.

Brown, G. K., Murphy, D. J., Miller, J. T., \& Ladiges, P. Y. (2008). Acacia s.s. and its relationship among tropical legumes, tribe Ingeae (Leguminosae: 
Mimosoideae). Systematic Botany, 33, 739-751.

Butcher, P., Moran, G. F., \& Perkins, H. D. (1998). RFLP diversity in the nuclear genome of Acacia mangium. Heredity, 81, 205-213.

Byrne, M., Tischler, G., Macdonald, B., Coates, D. J., \& McComb, J. (2000). Phylogenetic relationships between two rare acacias and their common, widespread relatives in Sout h- western Austral i a. Conservation Genetics, 2, 157-166.

Byrne, M., MacDonald, B., \& Coates, D. (2002). Phylogeographical patterns in chloroplast DNA variation within the Acacia acuminata (Leguminosae: Mimosoideae) complex in Western Australia. Journal of Evolutionary Biology, 15, 576-587.

Clarke, H. D., Downie, S. R., \& Seigler, D. S. (2000). Implications of chloroplast DNA restriction site variation for systematics of Acacia (Fabaceae: Mimosoideae). Systemactic Botany, 25, 618-632.

Grace, M. B., Bambeck, G. S., Buzard, G. S., \& Wintraub, B. D. (1995). Transverse temperature-gradient single-strand conformation polymorphism analysis for temperature optimization of 'Cold'-SSCP mutation detection. Nucleic Acids. Res., 23, 42244226.

Guan, L., Suharyanto, \& Shiraishi, S. (2011). Isolation and characterization of tetranuceotide microsattelite loci in Pinus massiniana (Pinaceae). Am.J. Bot., 98, e216-e217.

Hattori, K. (1997). Sequencing methods for PCRamplified DNA. Experimental Medicine, 15(7), 711-717.

Hayashi, K. (1991). PCR-SSCP: A simple and sensitive method for detection of mutation in genomic DNA. PCR Methods Appl., 1, 34-38.

Hong, Y. P., Hipkins, V. D., \& Strauss, S. H. (1993). Chloroplast DNA diversity among trees, populations and species in the California closed-cone Pines (Pinus radiata, Pinus muricata and Pinus attenuata). Genetics, 135, 1187-1196.

Hongyo, T., Buzard, G. S., Calvert, R. J., \& Weghorst, C. M. (1993). 'Cold SSCP' : a simple, rapid and non-radioactive method for optimized singlestrand confor mation polymorphism analysis. Nucleic Acids Res, 21, 3627-3642.

Isoda, K., \& Shiraishi, S. (1999). Identification of chloroplast DNA haplotypes of Abies firma and A. homolepis using a polymerase chain reaction with species-specific primers. Journal of Forest Research, 4(4), 291-294.

Judelson, H. S., Spielman, L. J., \& Shattock, R. C. (1995). Genetic-mapping and non- Mendelian of mating-type loci in the Oomicete, Phytophthora-infestans. Genetics, 141, 503-512.

Khasa, P. D., Cheliak, W. M., \& Bousquet, J. (1994). Genetic variation in 26 populations of Racosperma auriculiforme and Racosperma mangium using allozymes. Can. J. For. Res., 24, 1123-1132.

Levy, F. J., Antonovics, J., Boynton, J. E., \& Gillham, N. W. (1996). A population genetic analysis of chloroplast DNA in Phacelia. Heredity, 76, 143155.

Maeda, H., \& Shiraishi, S. (1997). An identification of chloroplast DNA haplotypes of Larix kaempferi and L. gmelinii var. japonica using flouresencebased PCR SSCP analysis of rbcL gene. J. For. Res., 2, 187-188.

McDonald, M. W., \& Maslin, B. R. (2000). Taxonomic Revision of the Salwoods: Acacia aulacocarpa Cunn. ex Benth. and its allies (Leguminosae: Mimosoideae: section Juliflorae). Australian Systematic Botany, 13, 21-78.

Moran, G. F., Muona, O., \& Bell, J. C. (1988). Acacia mangium: A tropical forest tree of the coastal lowlands with low genetic diversity. Evolution, 43, 231-235.

Moran, G., Muona, O., \& Bell, J. C. (1989). Breeding systems and genetic diversity in Acacia auriculiformis and A. crassicarpa. Biotropica, 21, 250-256.

Orita, M., Iwahana, H., Kanazawa, H., Hayashi, K., \& Sekiya, T. (1989)). Detection of polymorphisms of human DNA by gel electrophoresis as single-strand conformation polymorphisms. Proc. Natl. Acad. Sci. USA, 86, 2766-2770.

Pettigrew, C. J., \& Watson, L. (1975). On the classification of Australian Acacias. Aust. J. Bot., 23, 833-847.ehben, H., G. Kress, and T. Schmidt. (1997). Application of PCR-SSCP to species identification of fishery products. J. Sci. Food Agric. 74: 35-41.

Rehben, H., Kress, G., \& Schmidt, T. (1997). Application of PCR-SSCP to species identification of fishery products. J. Sci. Food Agric., 74, 35-41.

Spinardi, L., Mazars, R., \& Theillet, C. (1991). Protocols for an improved detection of point 
mutations by SSCP. Nucleic Acids Res., 19(14), 4009.

Taberlet, P., Gielly, L., Pautou, G., \& Boubet, J. (1991). Universal primers for amplification of three non-coding regions of chloroplast DNA. Plant Mol. Biol., 17, 1105-1109.

Thompson, L. A. (1994). Acacia aulacocar pa, A.cincinnata, $A$. crassicar pa and $A$. wetarensis: an annotated bibliography. Canberra: Division of Forestry, Australian Tree Seed Centre.

Watano, Y., Imazu, M., \& Shimizu, T. (1995). Chloroplast DNA typing by PCR-SSCP in the Pinus pumila-P. parviflora var. pentaphylla complex (Pinaceae). J. Plant. Res., 108, 493-499.

Wickneswari, R., \& Norwati, M. (1993). Genetic diversity of natural populations of Acacia auriculiformis in Australia and Papua New Guinea. Aust.J. Bot, 41, 65-77.

Widyatmoko, A. Y. P. B. C., \& Shiraishi, S. (2011). Sequence polymorphisms of four hloroplast genes in four Acacia species. Journal of Forestry Research, 8(1), 79-89.

Widyatmoko, A. Y. P. B. C., Watanabe, A., \& Shiraishi, S. (2010). Study on genetic variation and relationships among four Acacia species using RAPD and SSCP marker. Journal of Forestr $y$ Research, 7(2), 125-144.

Wolfe, K. H., Li, W. H., \& Sharp, P. M. (1987). Rates of nucleotide substitution vary greatly among plants mitocondrial, chloroplast, and nuclear DNAs. Proc. Natl. Acad. Sci. USA, 84, $9054-$ 9058.

Zulfahmi, Siregar, I. Z., \& Siregar, U. J. (2010). Chloroplast DNA variation of Shorea acuminata Dyer in Eastern Sumatra assessed by mircrosatellite markers. Biodiversitas, 11(3), 107111. 
